\title{
C2C marketplace model in fishery product trading application using SMS gateway
}

\author{
Dwi Ely Kurniawan ${ }^{1, *}$, Nur Zahrati Janah ${ }^{1}$, Ari Wibowo ${ }^{1}$, Mir'atul Khusna Mufida ${ }^{1}$ and Purwono Prasetyawan ${ }^{2}$ \\ ${ }^{1}$ Politeknik Negeri Batam, Department of Informatics Engineering, Indonesia \\ ${ }^{2}$ Universitas Teknokrat Indonesia, Department of Electrical Engineering, Lampung, Indonesia
}

\begin{abstract}
Most people in Batam hinterland work as a fisherman. The process of the fishery product distribution, however, is inefficient. The absence of marketplace causes fishermen's difficulty in selling their fishery products. This sales and distribution problem can be mediated using our web application. This research attempts to facilitate customer to customer (C2C) transaction by providing fishery products information via text messages. The SMS gateway is deemed to be the best alternative in a rural area with poor infrastructure. Fishermen are only required to send information about their fishery product in a text message with their phone and the system will receive and display them. The payment is then done using the Cash on Delivery system (COD). This research concludes that the system runs smoothly; it can display the fishery product offers and manage the fishermen and their fishery product data. The SMS gateway test showed a good result in the experiment involving 10 consecutive texting with three different treatments.
\end{abstract}

\section{Introduction}

Most people in the coastal area depend their life on the sea. One of this area with high sea product potentiality is located in Riau Islands Province, Indonesia. Most of the natives work as a fisherman. Their work income, however, cannot cover their daily expenses. They must face the challenge brought about by poor infrastructure. These include, for example, the lack of boat to transport fish product and their high transport cost, and the lack of fish auction to collect, sell, and distribute their fishery product - which in turn lower the fish's quality. The long and complex chains of bureaucracy to obtain permit also hinder them [1-2].

The fishermen usually send their fishery product to a nearby TPI (Tempat Pelelangan Ikan, fish auction). However, there are only a few of these TPI; many places do not have it. The fishermen find it hard to sell their product most of the time; the product's marketing does not go well. Many fishermen sell their captures overseas through a broker. According to the Kelompok Usaha Bersama Nelayan Bina Batam Madani's Executive Chief, $90 \%$ of the captures is exported to Singapore [1]. The price offered here is indeed higher than in the domestic market. As an example, fishermen can sell ray fish for Rp 100.000,- per kilogram in Singapore, but only Rp 80.000,- per kilogram at most in the domestic market-hence, they prefer to sell them overseas. However, sometimes the price offered by the broker is inconsistent. On the other hand, the support is given by the government often does not reach the intended target or not of the kind the fishermen really need-caused by lack of monitoring and supervision [2]. Most fishermen find difficulty in selling their capture since there is practically no place where they could sell their capture and insufficient marketing [3].

Technology is advancing. Almost everybody, possibly fishermen too, own communication devices, such as cellular phone-used in their communication when they go fishing in the sea. The following figure shows the fishermen's accessible information technology on the national level: $82.3 \%$ on television, $64.8 \%$ on cellular phone, $12.8 \%$ on radio, and $8 \%$ on the internet [4].

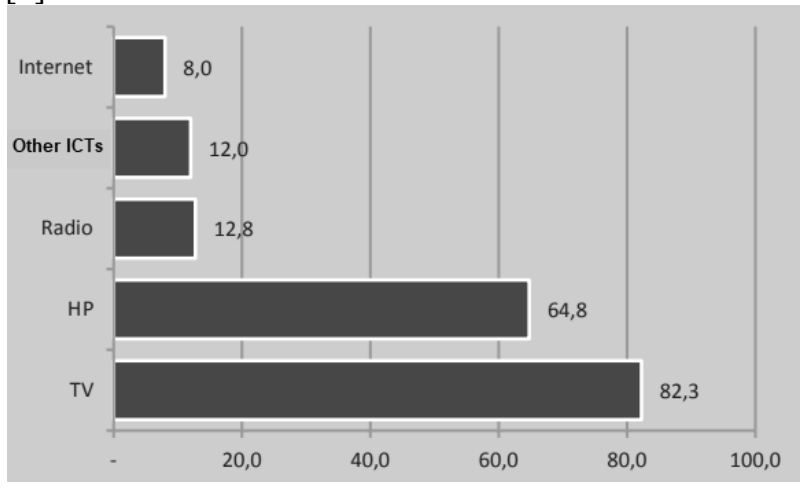

Fig. 1. Fishermen's possession and access to information technology [4].

Figure 1 shows a fairly good level of fishermen's information technology possession and access, such as via cellular phone. The device will also support communication in the context of marketing. It is clear that their general means of communication is still face to face-that of the traditional one [5]. However, considering their background education, 56.3\% and

\footnotetext{
* Corresponding author: dwialikhs@polibatam.ac.id
} 
$18.8 \%$ are elementary school and junior high school graduates respectively, their usage and application of communication device can be considered to be relatively good. Cellular phone [5] and other devices [6] have been used to enhance their communication and to fulfill their information needs. Most of them spend 2 to 3 days in their home to access the internet on their devices. The top three activities involving this internet access are searching for information about the fishery, accessing social media sites, and surveying the market [4]. This shows a fair level of mastery on their use of information and communication technology devices.

Other researchers which are also concerned with fishermen's problems include the application of integrated fishery information system service-using web server, SMS gateway, and sky eye satellite imagery - to increase the amount of fish capture [7], the desktop-based natural resources and fishing area management information system using ArcView-to show fishing spots - [8], and to provide Cold Storage House Prototype with solar in supporting fish-eries production and marketing with cheap and profitable so that can be mass-produced [9].

From the above description, we can conclude that even though the number of nearby fish auctions are few, the fishermen's percentage of information and communication technology devices possession and knowledge, especially cellular phone, is high-further enhanced by their solid network. This research then attempts to develop a fishery product trading application. Previous researchers have not yet explained how the marketing should be done to improve fishermen's welfare. It is hoped that the application can facilitate a simpler transaction process between the fishermen and the customer in a web system. This system might seem to resemble the Go-Jek Indonesia and other similar mobile applications (https://www.go-jek.com). However, here the system is not based on the Android platform, because of the poor network infrastructure in the coastal area. Fishermen use their cellular phone while they are going to the sea. This research offers a means of communication utilizing text message, which was supported by most cellular phones. The information in the text message contains the fishery product information. The message will then be sent to the server to be displayed on the online trading website.

Nowadays e-commerce has pervaded every corner through innovation and creativity, reducing the providercustomer gap. E-marketplace-where seller and customer meet and do transactions $(\mathrm{C} 2 \mathrm{C})$ - is a part of ecommerce [12]. Previous research regarding marketplace in Indonesia reveals that the factors affecting the performance of e-marketplace include satisfaction, image, price, promotion, and value-added service. Of all this, satisfaction has the biggest influence on the emarketplace seller's loyalty $[10,13]$. Moreover, in 2017 Google launched their new search engine Google Shopping (https://www.google.com/shopping?hl=id). This site indexes most of the e-marketplaces existing up until today.

\section{Method}

As described above, there are only a few to no marketplace where the fishermen could sell their product, but their possession of information and communication technology devices and their ability to utilize them is high. However, their use of these devices is mostly on entertainment and leisure. To address this problem, this research tries to identify the system requirements based on both the user and the existing information technology supporting environment. The device needed by the fishermen to communicate when they go fishing on the sea is, at least, a cellular phone. A cellular phone will be used to send a text message to the SMS Gateway server. The server system will be provided by the broker or another vendor, so the fishermen will only need to use their phone to do transactions involving their captures. This research uses waterfall-by first identifying the system requirements in the software development - as its method. In short, the system centers around the online trading website provider's system administrator who will send the text message sent by fishermen to the server, which will then validate the message for its integrity. This technology utilizes the SMS Gateway server. This fishery product trading system design is illustrated in Figure 2 below.

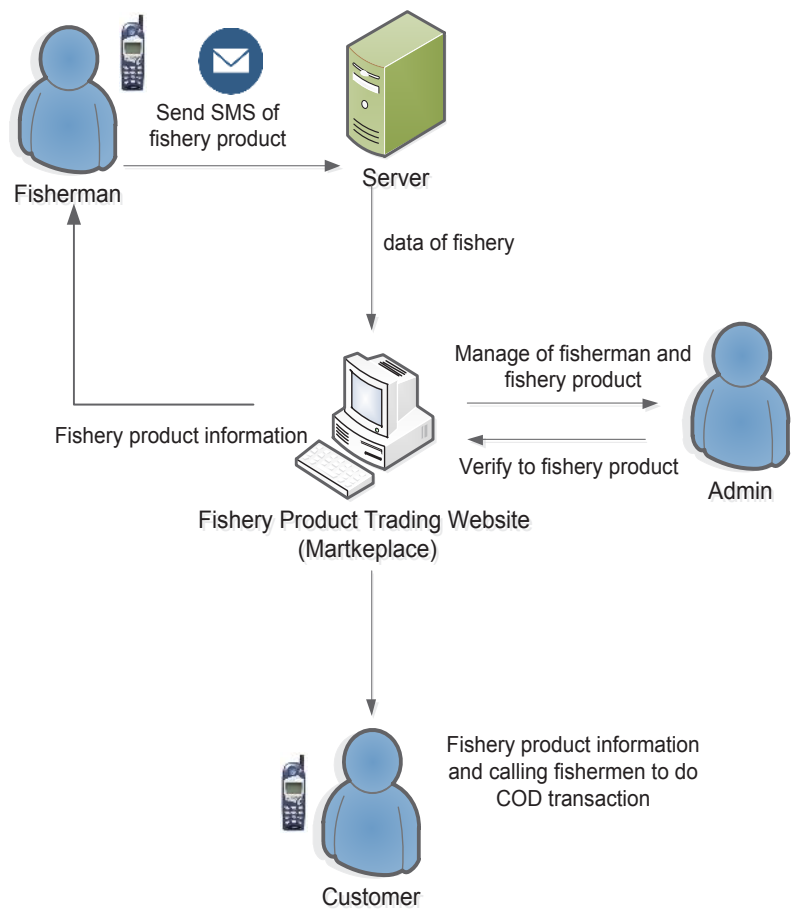

Fig. 2. The fishery product trading system design.

Figure 2 shows the online fishery product trading system. The data containing the detail information sent by fishermen will be displayed on the fishery product trading website. The customer can see the information provided by the broker's web server (e-marketplace) and may contact the fishermen directly to make the purchase if they are interested in the product. The customer and the fishermen can then arrange a meeting to make the deal. The transaction will be done in the agreed location (Cash on Delivery-COD system) to ensure trust [14]. 


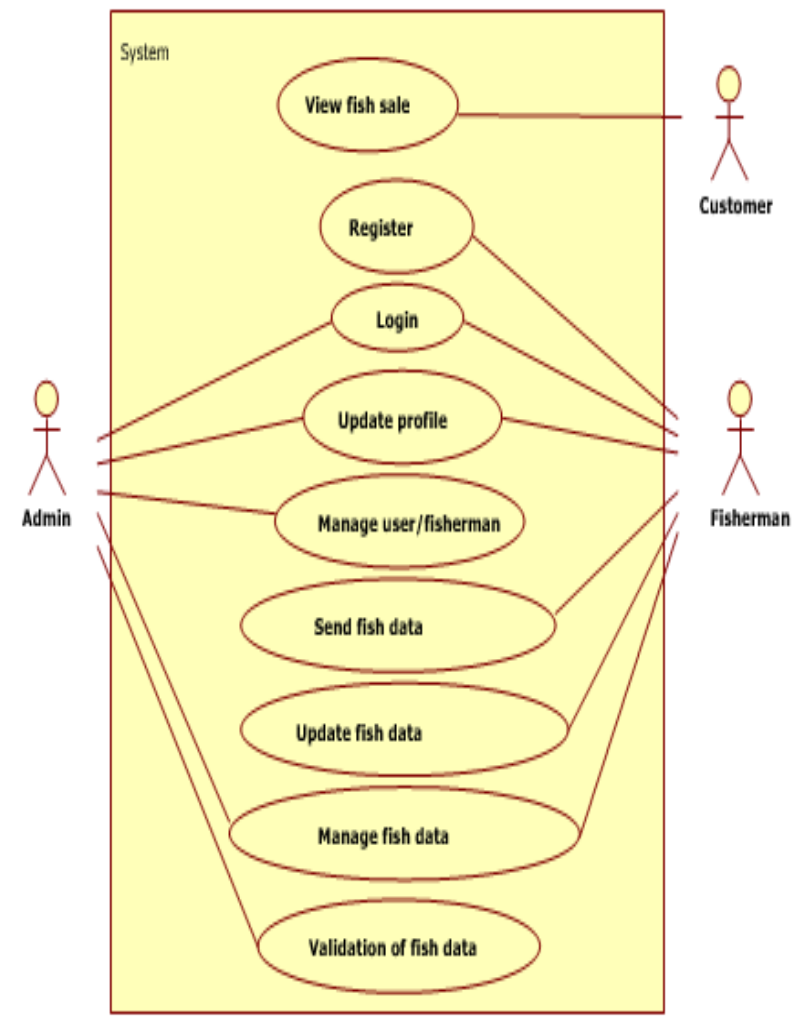

Fig. 3. Fishery product trading use-case diagram.

Figure 3 shows that the user interaction of the application to be developed. In this application, fishermen can register to the application, change their profile, and manage or send their fishery product data. The administrator can manage or add user or fishery product data and validate the data that will be displayed. The user can interact with the system to view the fishery product offers. They will be able to see the data containing the information of the product and the seller to be contacted to make the purchase if they wish to do so.

\section{Results and discussion}

The $\mathrm{C} 2 \mathrm{C}$ marketplace website design has been optimized to meet the application's requirements. The website's server implements MySQL and Gammu in Ubuntu 11.04 operating system with the specification that is equivalent to a $2 \mathrm{GHz}$ Dual Core processor, $1 \mathrm{~GB}$ RAM, and $80 \mathrm{~GB}$ storage PC.

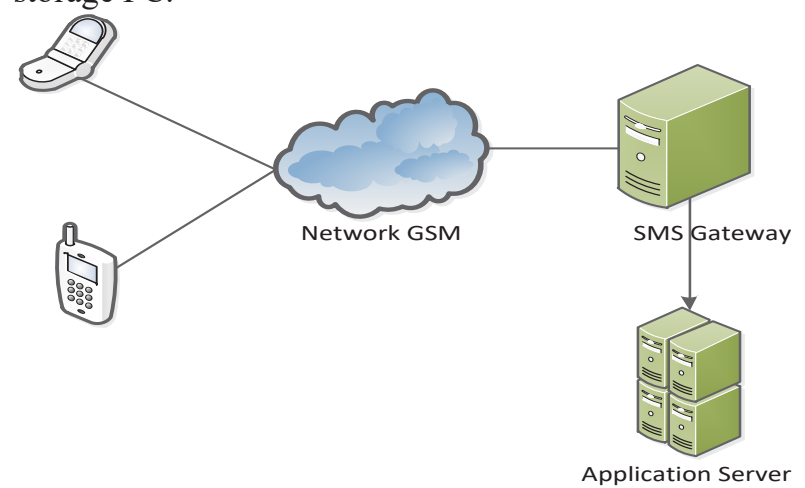

Fig. 4. The SMS gateway architecture.
Gammu is a tool employed to develop SMS gateway. SMS gateway is chosen because it is free, works on the Linux platform, and supports more devices [12]. SMS gateway enables a cellular phone and a computer to interact in a network through a text message, as long as they are connected to GSM network. The text message sent by fishermen will be stored in the SMS gateway server, which will then be directed to the web marketplace application server.

\subsection{The implementation of C2C marketplace website}

The implementation of $\mathrm{C} 2 \mathrm{C}$ fishery product marketplace website's front page is shown in figure 5. Fishermen must first register themselves to the fishery product emarketplace trading website by providing their profile data. Once registered, they can send their fishery product data via a text message. The customer can view, search, and choose a fishery product directly. The displayed items will be updated when fishermen send a message to the SMS gateway server. All of the messages will be displayed instantly on this page. The administrator will then perform a validation if there is a mismatch in fishery product.

localhost/nelayan/level/pembeli/index.php
localhost/nelayan/level/pembeli/index.php
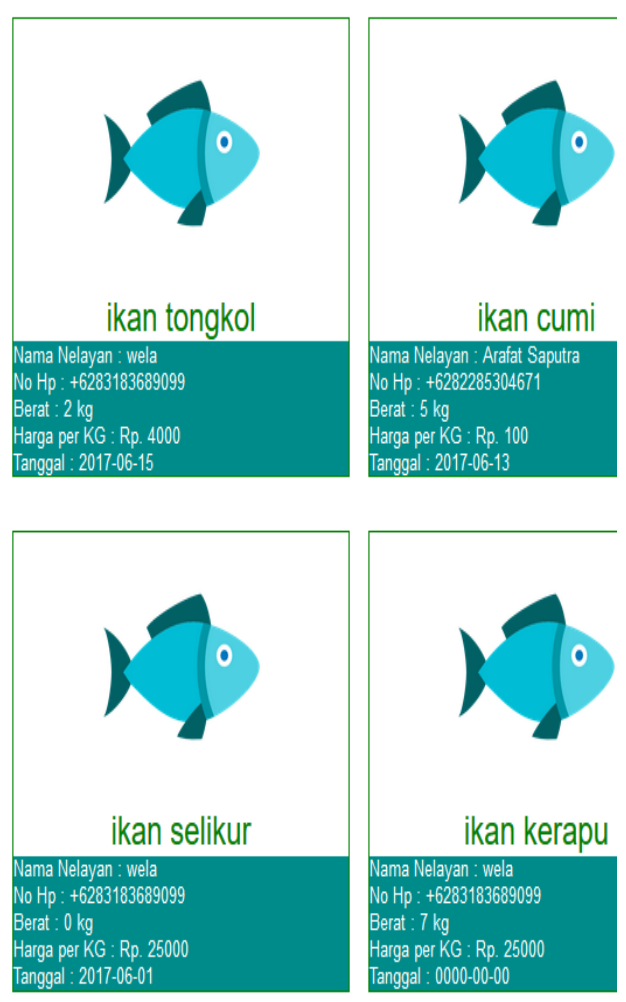

Fig. 5. The $\mathrm{C} 2 \mathrm{C}$ fishery product trading website $\mathrm{C} 2 \mathrm{C}$ marketplace.

The data containing the fishery product offer information will be updated by sending a text message in a predefined format. The format for adding, deleting, and editing fishery product data is different. These are shown in Table 1 below. 
Table 1. The text message format for updating fishery product data.

\begin{tabular}{|c|c|c|}
\hline Activity & $\begin{array}{c}\text { Message } \\
\text { Format } \\
\text { Example }\end{array}$ & Notes \\
\hline $\begin{array}{l}\text { 1. } \\
\text { Adding } \\
\text { fishery } \\
\text { product } \\
\text { data }\end{array}$ & $\begin{array}{l}\text { Tambah\#ikan } \\
\text { mas\#4\#20000 }\end{array}$ & $\begin{array}{l}\text { Tambah - followed by the } \\
\text { product, its weight (in } \\
\text { kilograms), and the } \\
\text { price-is used to add } \\
\text { fishery product data. }\end{array}$ \\
\hline $\begin{array}{ll}\text { 2. } & \text { Editing } \\
& \text { fishery } \\
\text { product } \\
\text { data }\end{array}$ & $\begin{array}{l}\text { Ubah\#ikan } \\
\text { mas\#4\#20000 }\end{array}$ & $\begin{array}{l}\text { Ubah-followed by the } \\
\text { product, its weight (in } \\
\text { kilograms), and the } \\
\text { price-is used to edit } \\
\text { previously sent data. }\end{array}$ \\
\hline $\begin{array}{ll}\text { 3. } & \text { Deleting } \\
\text { fishery } \\
\text { product } \\
\text { data }\end{array}$ & $\begin{array}{l}\text { Hapus\#ikan } \\
\text { mas }\end{array}$ & $\begin{array}{l}\text { Hapus is used to delete a } \\
\text { category of fishery } \\
\text { product data. }\end{array}$ \\
\hline
\end{tabular}

The message can be sent by fishermen from everywhere, as long as they are connected to GSM network, which means that this can be done on the sea and they can directly meet the customer if a deal has been met, once they are ashore. The customer is assumed to have seen the information and contacted the corresponding fishermen to meet in order to make the deal once he is ashore, thus potentially reducing the transport cost. The customer can purchase relatively cheaper fresh fish this way than from a broker or any market. The fishery product e-marketplace website data updating process is shown in Fig. 6. After sending the message to the SMS gateway server, fishermen will receive a reply informing that the data has been updated.

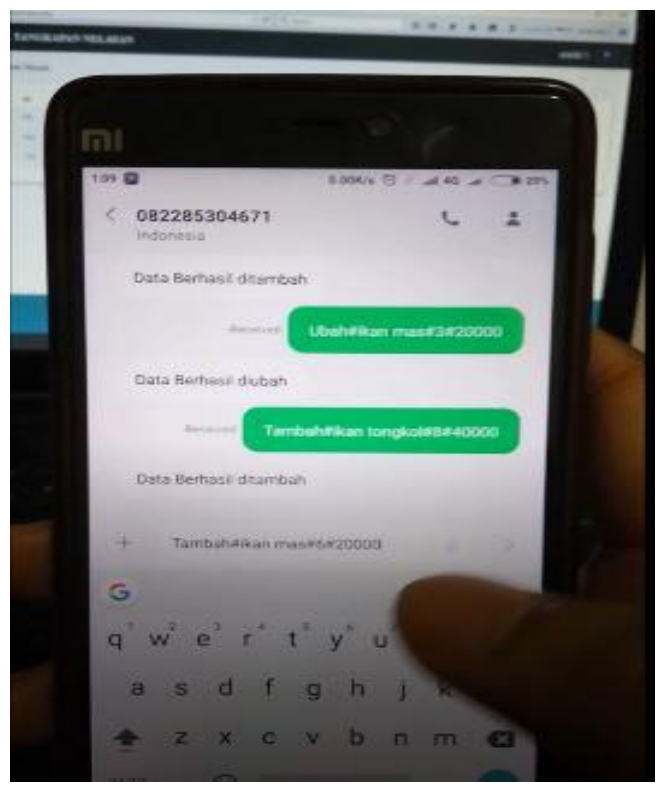

Fig. 6. Updating fishery product trading website via text message.

Fig. 7 shows the message format-adding 3 kilograms of goldfish (ikan mas) that will be sold for Rp 20.000 ,- each, with Rp 60.000,- in total, by a fisherman named Wela.

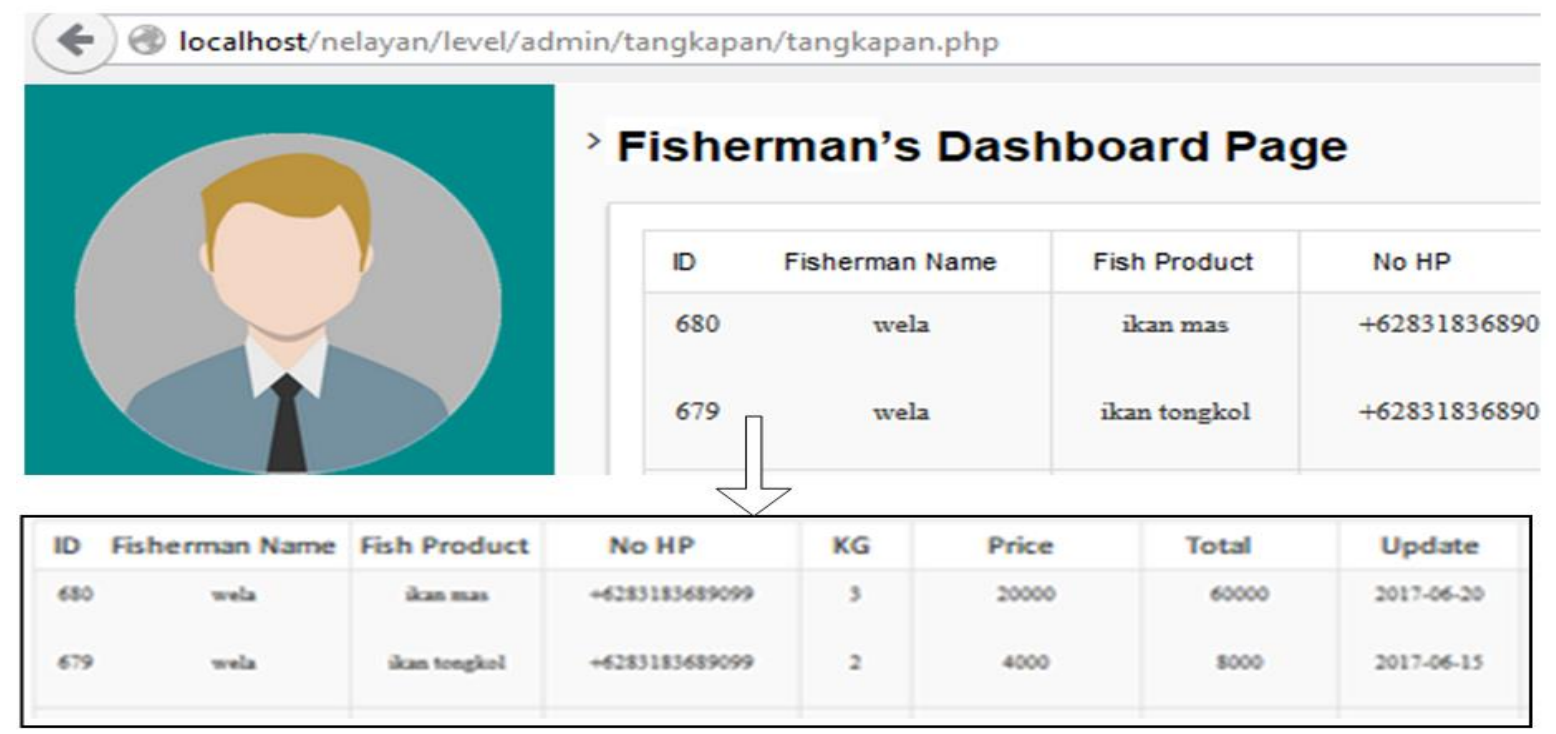

Fig. 7. The fisherman's dashboard page.

The fishery product will be displayed on the front page at the time of the update. The data containing fishery product offers are as shown in Figure 5. The displayed fishery product information including fisherman's name, phone number, fish weight, its price per kilogram, and the date the product information was posted. Most importantly, the phone number will be used by the customer to contact the fisherman to make the purchase.

\subsection{Testing}

The test has been done by sending several text messages to the SMS Gateway server. The system would only accept the message sent by registered phone number, which would then be displayed on the fishery product trading website. Unregistered numbers could not be recognized by the SMS Gateway server and were flagged as spam. The phones used in this test were Asus Zenfone and Xiaomi or low specification. This texting test is summarized in Table 2 below. 
Table 2. SMS gateway testing treatments.

\begin{tabular}{|c|c|c|c|c|c|c|c|c|c|c|}
\hline $\begin{array}{l}\text { SMS Gateway } \\
\text { Treatments }\end{array}$ & 1 & 2 & 3 & 4 & 5 & 6 & 7 & 8 & 9 & 10 \\
\hline $\begin{array}{l}\text { 1. Texting } \\
\text { using the same } \\
\text { provider as the } \\
\text { server }\end{array}$ & $\mathrm{V}$ & $\mathrm{V}$ & $\mathrm{V}$ & $\mathrm{V}$ & $\mathrm{V}$ & $\mathrm{V}$ & $\mathrm{V}$ & $\mathrm{V}$ & $\mathrm{V}$ & $\mathrm{v}$ \\
\hline $\begin{array}{l}\text { 2. Texting } \\
\text { using a } \\
\text { different } \\
\text { provider from } \\
\text { the server }\end{array}$ & - & $\mathrm{V}$ & $\mathrm{v}$ & $\mathrm{v}$ & $\mathrm{v}$ & $\mathrm{v}$ & $\mathrm{V}$ & $\mathrm{v}$ & $\mathrm{V}$ & $\mathrm{v}$ \\
\hline $\begin{array}{l}\text { 3. Simultaneous } \\
\text { texting }\end{array}$ & $\mathrm{V}$ & $\mathrm{V}$ & - & $\mathrm{v}$ & $\mathrm{V}$ & $\mathrm{V}$ & $\mathrm{V}$ & $\mathrm{V}$ & $\mathrm{v}$ & $\mathrm{V}$ \\
\hline
\end{tabular}

Table 2 shows the three different test treatment in sending 10 consecutive text messages to the SMS gateway server. The first treatment has been done using the same provider as the server-which was successfully done. The second treatment has been done using a different provider from the server. This resulted in one unsent message (the first message). The third treatment was done by sending the messages simultaneouslywhich also resulted in one unsent message. The experiment shows that the SMS gateway server did a good job in receiving text messages sent by fishermen.

\section{Conclusion}

From the implementation and test result described above, it can be concluded that in a fishery product trading process, fishermen must first register themselves to the fishery product e-marketplace trading website by providing their profile data. Once registered, they can send their fishery product data via a text message. The information will be received and then displayed in the emarketplace website's main page by the system. The emarketplace website will provide current fishery product information to the customer. The fishery product offer information will be updated by sending a text message in format for adding, deleting, and editing fishery product data. The payment, however, will be done using Cash on Delivery (COD) system, after the delivery. The SMS gateway test showed a good result in the experiment involving 10 consecutive texting with three different treatments.

Authors thank P3M Politeknik Negeri Batam and everyone in Department of Informatics Engineering who have helped us finishing this study. We also thank M. Arafat for helping us collecting the data and developing software for our study.

\section{References}

1. Erlangga D. Harga Lebih Mahal, 90 Persen Ikan dari Batam Diekspor ke Singapura [Price More Expensive, 90 Percent of Fish from Batam Exported to Singapore] Regional Kompas Newspapers [Online] from https://regional.kompas.com/read/2016/10/13/13274 971/harga.lebih.mahal.90.persen.ikan.dari.batam.die kspor.ke.singapura [Accessed on April 23th 2018]. [in Bahasa Indonesia] (2018)

2. Setijadi, S. Teknologi Informasi dan Komunikasi Untuk Sistem Logistik Ikan Nasional FGD Komponen Teknologi Informasi dan Komunikasi Sistem Logistik Ikan Nasional (SLIN) Supply Chain Indonesia Kementrian Kelautan dan Perikanan [Information and Communication Technology for National Fish Logistics System FGD Information and Communication Technology Component National Fish Logistics System (SLIN) Supply Chain Indonesia Ministry of Marine Affairs and Fisheries] p 1-18, (2015).

3. Cahaya, A., Fishermen community in the coastal area: A note from Indonesian poor family. Procedia Economics and Finance, 26, pp.29-33. (2015)

4. Pusat Penelitian dan Pengembangan Pos dan Informatika [Online] from https://balitbangsdm.kominfo.go.id/?mod=publikasi $\& \mathrm{a}=$ dl\&page_id=148\&cid=29\&download_id=114 [Accessed on April 23th 2018]. [in Bahasa Indonesia] (2018)

5. Trisnani, T. Society Communication Patterns In The Era Of Information Technology Case Study Coastal Village, Besuki District, District Situbondo J Penelitian Komunikasi dan Opini Publik 20(2): 141154 (2016)

6. Asirin, A., \& Argo, T. A. The Use of Information and Communication Technology and Its Implication on The Livelihood Resilience of Fishermen. J of Regional and Rural Development Planning, 1(1), 115 (2017)

7. Dwiandiyanta, B. Y. Analisis dan Perancangan Sistem Informasi Perikanan Terpadu bagi Nelayan Tradisional berbasis Mobile, (2011)

8. Mustaruddin, M., Simbolon, D., \& Handoyo, K. Development of Management Information System of Capture Fishery Resources and Environment in Padang Pariaman Regency, West Sumatra. Buletin PSP, 20(2), 143-154 (2013)

9. M. Ikhsan Setiawan et al., Inflated Portable Cold Storage House with Solar Cells as facilities to support the fisheries production and marketing. Int. J of Engineering \& Technology. 7, 323-326 (2018)

10. Napitupulu, T. A., \& Aditomo, H. C. The Factors affecting customer loyalty in Business e-commerce: A case of Indonesia. J of Theoretical \& Applied Information Technology, 76(3) (2015)

11. Kurniawan, D. E., \& Fajrianto, R. Sistem Pemantau Koneksi Internet Menggunakan Sistem Informasi Geografis dan SMS Gateway. In SISITI: Seminar Ilmiah Sistem Informasi dan Teknologi Informasi (5)1 (2017)

12. Albrecht, C. C., Dean, D. L., \& Hansen, J. V. Marketplace and technology standards for B2B ecommerce: progress, challenges, and the state of the art. Information \& Management, 42(6), 865-875 (2005) 
13. De Silva, D. A. M. Value chain of fish and fishery products: origin, functions and application in developed and developing country markets. Food and Agriculture Organization. 63pp (2011)

14. Birdsall, N., Savedoff, W. D., Mahgoub, A., \& Vyborny, K. Cash on delivery: a new approach to foreign aid. CGD Books (2012) 